\title{
Securing the Future of the Community: Child Protection in ASEAN
}

\author{
Palapan Kampan ${ }^{1,2}$ \& Adam R. Tanielian ${ }^{1,2,3}$ \\ ${ }^{1}$ National Institute of Development Administration, Bangkok, Thailand \\ ${ }^{2}$ Institute of International Studies, Ramkhamhaeng University, Bangkok, Thailand \\ ${ }^{3}$ Disney English, Chengdu, China \\ Correspondence: Adam R. Tanielian, Disney English, $2^{\text {nd }}$ Fl. Cai Fu You Yi Cheng, N. Hongxing Rd., $1^{\text {st }}$ Ring, \\ Chenghua District, Chengdu, Sichuan 610000, China. E-mail: adam.tanielian@gmail.com
}

Received: February 21, 2014 Accepted: April 5, 2014 Online Published: May 30, 2014

doi:10.5539/ass.v10n11p172 URL: http://dx.doi.org/10.5539/ass.v10n11p172

\begin{abstract}
This article reflects upon effects of the Convention on the Rights of the Child and related treaties since their inception, with a focus on the ASEAN group. Literature, legal and statistical review and analyses show successes and failures on several points: nutrition, child soldiers, child sexual exploitation, HIV/AIDS, substance abuse, child labour, violence, and education. The research found abuse of children's rights is high enough to warrant serious concern. Violations of rights both come from and lead to deep poverty, leaving the ASEAN community vulnerable in the present and future. Creative, aggressive policy changes are promoted while universal acceptance and enforcement of children's rights, like any human rights, are likely to succeed or fail due to actions or inactions in smaller social segments and communities.
\end{abstract}

Keywords: ASEAN, children's rights, economics, human rights, international law

\section{Introduction}

The Universal Declaration of Human Rights, while not a treaty per se, is considered the foundation of international human rights law (UN, 2013). Broader historical human rights emerge from international customary law, some intersecting with jus cogens, or peremptory norms, which prohibit genocide, slavery, human trafficking and racial discrimination (Cornell University, 2013). Treaties addressing other aspects of human rights, such as expression, religion, employment, education and health care exist because states agree that such principles should be written into law, and that people should be the subjects of such rights.

Argument has been made that children cannot be holders of rights due to legal and intellectual capacity, and because of problems relating to the exercise of rights while a minor (Archard, 2010). Such arguments are easily held irrelevant because, in fact, children do have rights and adults have duties to protect those rights. The 1989 Convention on the Rights of the Child (CRC) is a milestone treaty which outlined fundamental rights of children to life, nationality, religion, expression, health care, education, and freedoms from exploitation or abuse. The CRC is the most widely ratified international human rights treaty, with only the United States and Somalia withholding ratification. Optional Protocols accompany the CRC and address in further details the involvement of children in armed conflict, and the sale of children, child prostitution, and child pornography.

States are the primary subjects of international law (Fidler, 2013), giving treaties little effect at the individual level. Law may be formulated at the international level, but laws are and rights are implemented, exercised and enforced at municipal levels. The Vienna Convention on the Law of Treaties binds State parties to perform treaty obligations, but States hold broad discretionary privilege over application of their internal laws, while individuals lack an international forum for petition or redress of any grievance, and other States must respect principles of sovereign equality and territorial integrity under the United Nations (UN) Charter. As such, broad differences are found between nations in the area of execution of human rights laws, while Constitutional and statutory language often suggests a more uniform set of theoretical objectives.

This article reflects upon effects of the CRC and related treaties since their inception, with a focus on the ASEAN group. Successes and failures are considered on several points: nutrition, child soldiers, child sexual exploitation, HIV/AIDS, substance abuse, child labour, violence, and education. As part of preparation for the 2015 launch of the ASEAN Economic Community (AEC), issues relating to children's rights in ASEAN are 
analyzed with the aim of providing information and conclusions that can help improve conditions in the region. Creative, aggressive policy changes are promoted. Ultimately, the future of the AEC is in the hands of families and individuals in the region, without whose cooperation, children cannot enjoy rights they are guaranteed under international and domestic laws.

\subsection{Methodology}

This research focuses on secondary data including literature, legal materials, and statistics relevant to child protection and children's rights. Aims of the study were to assess both successes and failures in the area of child protection, and to offer suggestions for continued improvement in view of apparent systemic or paradigmatic shortcomings. Inclusion of numerical data implies some element of quantitative methods in the research, however, the enormous scope of societies under study in combination with the extreme secrecy accompanying criminal practices created epistemological conflicts. While the statistical data retrieved from secondary sources were not disputed, we approached such numbers as estimates and reference cases which supported opinions on issues or demonstrated need for further action.

Qualitative methods supported broader legal analysis and literature review. Subjectivity associated with morality and deontological ethics was preempted by legal positivism. Conflicts of legal ideals were mitigated by ranking paradigms from international to local jurisdictions. De lege ferenda recommendations for executive and legislative branches are proffered in support of existing principles at multiple levels. Pragmatism was also a concern during formation of conclusions. We undertook the research with the outlook that our systems are fundamentally imperfect and subject to multiple constraints, thus making no singular plan or criticism universally valid. Considering that consequential harm persists short of massive improvements in child protection systems, and given the limited economic resources available, our interpretations of the data are made with a sense of eclectic utilitarianism, whereby our ultimate goal is mere universal children's rights in practice.

\subsection{Research Procedure}

All data and materials were collected from secondary sources. Most of the searches were conducted via electronic databases using keyword strings such as "child protection", "human rights", "child abuse", and associated terms that were mentioned in multiple texts relevant to the research. Documents were initially sorted into "legal" and "article" categories. The "legal" category included treaties, statutes, constitutions, and cases. The "article" category contained academic, governmental, intergovernmental, and NGO research findings. Upon review of the documents, we found eight main themes: nutrition, child soldiers, child sexual exploitation, HIV/AIDS, substance abuse, child labour, violence, and education. Literature, statistics, and legal documents were again separated by theme for analysis and interpretation.

\section{Convention on the Rights of the Child: 25 Years of Mixed Results}

State parties to treaties like the CRC are bound to enact laws implementing certain provisions, but sovereign states also exercise discretion when interpreting obligations and developing domestic enforcement systems. The result is uneven application of treaty provisions between and among nations. Due to differences in legal system or tradition, or relating to public budgets, treaties often serve as guiding principles or ideals which are not always considered pragmatic. Ultimate power in any municipal jurisdiction is vested in local, state, federal, or other domestic government. Thus, while states have formally agreed that children are rights holders, abuse of those rights is still prevalent (VOA, 2009; UNICEF, 2013). Notwithstanding the need for further protection and enforcement of children's rights, the CRC and its Optional Protocols led to constrained successes.

\subsection{Nutrition}

Consistent progress has been made worldwide through application of CRC Articles 24 and 27 and implementing policies at the domestic level. Cambodia, Indonesia, Laos, Philippines, Thailand and Vietnam saw prevalence of undernourishment decrease from an average $36 \%$ of the population in 1990 to $14.5 \%$ in 2011 (World Bank, 2013). Prevalence of stunting in Southeast Asia saw an estimated decline from about $43 \%$ of children in 1990 to around 28\% in 2005 (Gillespie, Haddad, \& Allen, 2001). However, while conditions have improved in recent decades, prevalence of malnutrition in Southeast Asia is greater than the average among developing nations (WHO, 2013).

Proper diet and growth is not a superficial concern, nor is being underweight or malnourished merely a matter of cultural perception. Potterton (2009) found malnutrition related to $60 \%$ of deaths in children under five. Another study found malnourished children are 20\% less literate (Save the Children, 2013). FAO (2012) stated "adequate nutrition is essential for economic growth, good health and physical and cognitive development". In 2007, the depth of hunger in East and South Asia were tied for the highest in the world, with no improvement over the 
previous decade unlike in Sub-Saharan Africa (ibid). While some quarter of the world's children have been considered "seriously underweight" (UNICEF, 2006a), those numbers have been higher in developing ASEAN states. UNICEF (2006b) estimated six million children under the age of five were underweight in Indonesia, three million in Philippines, and two million in Vietnam. A two-way relationship is noticed, wherein poor economic and social conditions lead to and emerge from poor nutrition.

\subsection{Child Soldiers}

CRC article 38, referring to customary International Humanitarian Law Rules 136-7, proscribes recruitment and involvement of children in armed conflict. Numerous other multilateral agreements likewise ban use of child soldiers, which is listed as a war crime under Article 8 of the Rome Statute. In the ten years following the Optional Protocol, use of child soldiers decreased significantly among state militaries (Lederer, 2008; Child Soldiers International, 2012). However, there are still believed to be some 800,000 active child soldiers worldwide, comprising about $40 \%$ of all armed forces (Kaplan, 2005; Chatterjee, 2012). Non-state militias, terrorist organizations, rebel forces and gangs now pose the greatest threat globally.

Longstanding conflicts in Southeast Asia draw attention to consistent use of child soldiers in the region. Myanmar has oft been cited as having the highest number of child soldiers in the world (Bachhuber, 2003; Tran, 2009; Healey, 2011). The Secretary General of the UN (2011) recently reported involvement of children in armed conflict in Myanmar, Philippines, and Thailand. These egregious violations of children's rights shed light on deficiencies of our international legal system, which operates on good faith standards whereby independent nations are solely responsible for honouring their agreements, with little to no feasible means of remedy for individuals.

\subsection{Modest Improvements Only Scratch the Surface}

Despite overwhelming political support for the CRC and Optional Protocols, the treaty itself has no direct authority within domestic systems, where laws are implemented and enforced. Two areas where there have been consistent improvements - child soldiers and nutrition - provide examples of the scope and severity of the larger issues, where each percent improvement represents only a drop in the bucket. Facts and figures suggest that protection of children's rights resembles that of adults' rights. There is some minimum level of enforcement, but no utopian paradise is emerging regardless of political and social interest.

"Too many children are growing up without basic health care, education and protection from abuse and exploitation," said UNICEF director Bellamy (UNICEF, 2004).

If the Millennium Development Goals (MDG) shall be met by most countries, a significantly redesigned strategy will be required.

\section{ASEAN 2015: New Approach Needed}

Scheduled to launch in 2015, the AEC could be a breakthrough in regional political, social, cultural, environmental and economic relations. Considering the population diversity and social dynamics of the region, increased flow of goods, services, capital, labour and people also poses unique threats to public safety, health, security, and wellbeing. For the AEC to be as successful as its proponents wish, both public and private sectors in ASEAN will need to undertake some fairly radical changes. Handshakes and document signings among politicians alone will not be enough to ensure a smooth transition into a harmonized union. Massive grassroots and informal local efforts will be crucial in building any sustainable development, peace and stability in Southeast Asia. Enforcement is vital in the short term, and a cultural transition needs to occur in the medium to long term.

\subsection{Child Sexual Exploitation}

Southeast Asia has long held the dubious distinction of having one of the world's largest populations of child prostitutes. Estimates of the exact number of children involved in illicit sex trades vary, but presence of minors in tourist brothel establishments is well-known in places like Thailand, Cambodia, and the Philippines, among which there could be roughly one million child prostitutes (Mehta et al, 1998; Tumlin, 2000; Jacquemin, 2011). Numerous studies have exposed the scourge of child sex exploitation in ASEAN, linking the trade to organised crime, disease, psychiatric illness, poverty, statelessness, and corruption (Tanielian, 2013).

The region's tropical climate, pristine beaches, and open-door visa policies make it a popular international travel destination, but what is good for the tourism industry is also bad for society as sex tourists troll the bars and towns for exotic thrills. An American Ambassador to the Philippines estimated that " $40 \%$ of foreign tourists come to the Philippines for sex" (Rosales, 2011). That figure is suspected to be closer to $60 \%$ in Thailand, where 
sex is "an essential economic pillar" (Rusing \& Urbina, 2005; Shahabudin, 2012). These statistics are in spite of statutory prohibition of all prostitution in those nations (Note 1). Evidence of a failure to protect is found in the fact that prostitution, including child prostitution, proliferates openly and freely throughout the region, without significant prevention or enforcement by public or private sectors. All ten ASEAN members have laws prohibiting sex trafficking and exploitation of minors (INTERPOL, 2010), yet the region has become a prime destination for child sex tourists (Bergman, 2013).

Cases like United States v. Kent Frank (Note 2) and Regina v. Klassen (Note 3) caught media attention and showed extraterritorial law enforcement is possible in response to grave human rights abuses like child sex tourism, but such actions cannot abrogate domestic authority. The territoriality principle of international law generally supplants the nationality principle. Hence, cooperation between states can aid in prosecution for criminal offenses, whether in the nation where the offense occurred or in the nation to which the accused belongs, but a foreign nation may not conduct investigations or make arrests abroad without explicit permission from the state in which such actions are undertaken. Consequently, responsibilities for enforcement and adjudication are best left to the sovereign nation in which offenses occur.

Eradication of any criminal trade is usually an unrealistic target, but reduction by more than half within ten years would probably be feasible with the right type and amount of attention. Reactive policing is perpetually required, but to tackle thorny turpitude such as child sex trades, proactive policing and heavy community involvement are essential. Government officers and civilians alike should take independent initiative to gather and disseminate information, analyze issues, and develop strategies that go beyond mere education on the topic.

Neighbourhood watches, community hotlines, peer-counseling, and early detection initiatives must provide a support system which not only rescues those caught in illicit trades, but prevents new entrants. Comprehensive, effective protection systems will undoubtedly challenge cultural norms related to privacy, the status quo regarding expressing dissent, and traditional Confucian opposition to legalism and coercive state power (Bloom, 2009; Deng, n.d.). Without changes in attitudes toward communicating openly and honestly about social ills, progress will be minimal.

\subsection{HIV/AIDS}

Like most macro public health and crime statistics, numbers of HIV/AIDS infections are inexact. Statistical uncertainty and social taboos increase the complexity of these problems. Since researchers first began to understand HIV/AIDS, we have known that it is associated with drug use, sex work and human trafficking. What is sometimes overlooked is how the disease spreads across geographical regions. Rapid economic growth and mobility within and across national borders also affect how the disease impacts a society or region (UNESCO, 2004). With more than two million cases of HIV/AIDS in the Greater Mekong Subregion (GMS), relaxed international visa and travel restrictions within the AEC could lead to growth of HIV/AIDS infections.

A UNICEF (n.d.) study from Southeast Asia showed 30\% of sex workers aged 13-19 are infected with HIV. Thailand - the wealthiest nation in the GMS - has the highest rate of HIV infection in Southeast Asia (Bergman, 2013), showing the disease is not exclusive to the most impoverished. Ruangkanchanasetr et al (2005) found high risk behavior associated with HIV/AIDS, such as alcohol and drug use, was prevalent among adolescents in Bangkok. Studies have concluded that campaigns for condom use in commercial sex establishments have helped slow the spread of HIV/AIDS (UNICEF, n.d.), but limited or logistical growth models are not necessarily the most attractive trends. Rather, we should aim for a more parabolic curve to see a reduction in the total number of cases in the near future.

Reducing prevalence of HIV/AIDS requires dramatic changes in behavior and cognition among major sectors in society. Education and awareness campaigns, especially in primary and secondary schools, are imperative. However, education is perhaps the simplest component of a functional plan. Attitudes regarding the value of life will need to shift so that people who are aware of the disease can justify taking action to prevent its spread. High risk correlative behaviors must be corrected, which entails higher-order changes in socio-economic paradigms. With a love of life, and potential for a higher-quality life, people can more easily rationalize prudent lifestyles.

\subsection{Substance Abuse}

In 2003, the United Nations reported, "[t]he Asian and Pacific region has some of the toughest laws against drug abuse and drug trafficking. Yet, the region is losing the war on drug abuse. Increasing numbers of young people are joining the ranks of drug users. At the same time, the age of initiation into drug use is declining throughout Asia and the Pacific to as low as 12 years."

Studies of over the past decade have shown 5-7\% of Thai adolescents engage in drug use, with rates among boys 
reaching nearly 14\% (Pengpid \& Peltzer, 2013). Whereas Western teenagers use cannabis more often than other drugs, methamphetamine is the most commonly used drug among Thais. In 2010-11, Thailand ranked number four in the world for reported methamphetamine seizures (UNODC, 2013a). Year-on-year growth was $60 \%$ between 2011 and 2012, when 227 million pills were seized (UNODC, 2013b). Prevalence of people who inject drugs has decreased in Thailand, but the country remains a hub for heroin trafficking. Domestic Thai market preferences may have shifted away from the opiates the Golden Triangle nation was famous for in the 1960s-80s, but opium cultivation has stubbornly remained an issue. Narcotics Control Board Deputy Secretary-General Pitaya Jinawat reported most opium growers in the Kingdom are financed by local politicians or ex-state officials (Kheunkaew \& Khamthita, 2008). While estimated production for 2013 was low, Thailand's role in the Golden Triangle opiate trade is still active (Australia Network News, 2013).

Myanmar remains the primary suspected source of methamphetamine pills in East and Southeast Asia, and the world's number two producer of illicit opiate drugs (UNODCa-b, 2013). Opium cultivation has remained a persistent and increasing problem in Myanmar despite government campaigns to eradicate the drug (Stout, 2013). Among the three Golden Triangle nations - Myanmar, Laos, and Thailand - opium poppy production has risen for seven consecutive years (UNODC, 2013c). The region accounted for $18 \%$ of global illicit opium production in 2013 .

Children and young people in Southeast Asia are exposed not only to cultures and societies heavily affected by illicit drug cartel activity, but also to abuse of legal substances like alcohol and tobacco. While some people view illegal and legal drugs as separate issues, other studies confirm positive relationships among all risky behavior (UNESCAP, 2003; Kulsudjarit, 2004; Pengpid \& Peltzer, 2013; UNODC, 2013a). Psychoactive drugs are normal goods by economic terms, and studies show these positive correlations between income and legal and illegal drug use (Petry, 2000; IAS, 2011; Hu \& Stowe, 2013). As income rises within the AEC, so too do threats to public health and safety in the way of increased use of and exposure to a variety of legal and illegal drugs.

The problem of drug use among people under age 18 cannot be effectively addressed without taking a more comprehensive approach. Rather than merely stigmatizing illegal drugs and their users, experts in multiple disciplines related to public health, law, psychiatry, education and social sciences have overwhelmingly endorsed major overhauls to anti-drug strategies with the aim of creating "evidence-based policy" or moving away from rhetoric and ideology toward more scientific handling of the issues (International Centre for Science in Drug Policy, 2010; Obama, 2013).

Doctors and scientists involved in the Vienna Declaration believe that "we cannot end AIDS until we end the war on drugs", reflecting the complex matrix of associated ills. But ending the war on drugs in Southeast Asia would challenge a prime component of the political status quo. It is easily arguable that such a paradigm change would not be popular or appropriate in the region. Still, each year more experts admit that the war on drugs has failed (LEAP, 2013; Annan \& Cardoso, 2013; McDonald, 2013).

A $21^{\text {st }}$ century strategy for ASEAN could rely upon facts and statistics related to health and safety in general. Worldwide, alcohol use is the world's third largest risk factor for disease burden, whereas illicit drug use ranks $18^{\text {th }}$ (WHO, 2009). Drunkenness, rather than illegal drug intoxication, is associated with most murders and violent crimes (BJS, 2007; DrugScope, 2013). Public and private initiatives should focus on creating and sustaining a more functional community where risks are better managed and reckless behavior is not supported or ignored. Both alcohol and drug laws need to be enforced. Offenders and abusers need treatment and guidance options through local departments of health and groups like Alcoholics Anonymous and Narcotics Anonymous, whether inside or outside of correctional facilities (Smart Justice, 2013).

Real, sustained change throughout the AEC will require changes of mind, which are the most difficult changes to put into action. Children and young people will need to feel comfortable talking about their thoughts, feelings, and behavior related to illicit drugs and related issues. Creating a supportive atmosphere will not be simple, considering that popular government initiatives from the previous decade included extrajudicial killings of drug suspects (Economist, 2008). Until opinions, irrational fears and superstitions are replaced by solid facts and trust in science, progress will be minimal.

\subsection{Child Labour}

Every country in ASEAN except Myanmar ratified both the 1973 ILO Convention No. 138 regarding minimum working age, and 1999 Convention No. 182 concerning the worst forms of child labour. Article 32 of the CRC similarly requires a minimum age of employment, while Articles 33-36 pertain to the worst forms of child labour (i.e. slavery, sexual exploitation, child pornography, trafficking in children). Despite the popularity of these treaties among national legislatures, widespread violations are found in practice. Perhaps child labour is the most 
noticeable area where rhetoric and formal policy are starkly contradicted by daily practice. There certainly exist arguments on behalf of parents and community members which suggest child labour is necessary for basic economic survival, but those points do not change the gravity of the situation where children's rights are being openly and wantonly abused.

Minimum working age is 15 under Article 2(2) of Convention No. 138, yet UNICEF (2011) reported on five ASEAN member states wherein greater than 7\% of children age 5-14 were involved in labour. Although national laws state a minimum working age of 15 (Note 4), the World Bank (2013) estimated 35\% of children age 7-14 in Cambodia work, $13 \%$ in Philippines, and $15 \%$ in Thailand. Numbers were negligible in the wealthiest three countries in ASEAN - Singapore, Brunei, and Malaysia. Regional rates of child labour exceed worldwide averages for respective national income groups (ILO, 2013). Indonesia (Note 5), Laos (Note 6) and Vietnam (Note 7) labour laws allow some employment of persons under age 15, despite ratification of Convention 138.

No ASEAN member received a positive review from the US Department of State in the 2013 Trafficking in Persons Report. Cambodia, Malaysia, Myanmar, and Thailand were placed on the Tier 2 Watch List (2WL). It should be considered no coincidence that Thailand is a neighbour to each of the other three AEC members on the $2 \mathrm{WL}$, given that Thailand is frequently cited as the number one destination country for trafficking in the GMS (Punkrasin, 2008; IOM, 2012). Regardless of law, policy, ideology, religion or formal doctrine prohibiting these abuses, Southeast Asia is known for all of the worst forms of child labour (see ECPAT, 2013).

Changing the labour market will be a challenge for most nations in ASEAN, where large portions of the workforce are in agriculture. Reports showed children most frequently work in agriculture. GDP per capita (PPP) is less than US\$10,000 in seven of ten ASEAN member states (CIA, 2013). ASEAN has three of the world's least developed countries - Cambodia, Laos and Myanmar. Absent miraculous economic growth, community-led changes should be directed at the long term with more planned-parenthood, birth control, and education on family economics. Children should not be viewed as another farm hand. In the short and medium-terms, only government enforcement can make a dent. Schools will need to report absences against registries of local residents to make sure children are enrolled and attending. However, in the world of small, family-owned businesses, enforcement will interfere with perceived parental rights, and social harmony could be disrupted until people come to terms with living within the letter of their laws.

\subsection{Violence}

CRC Article 19 theoretically protects children from all forms of violence, while Article 28 protects them from violence in schools. Most violence against children relates to harmful traditional practices that have been normalized for millennia. $94 \%$ of children age 2-14 in Vietnam and $74 \%$ of children in the same age group in Laos reported experiencing violent disciplinary methods (UNICEF, 2011). UNICEF (2012) reported multiple studies from ASEAN showing trends of abuse. 30\% of Thai sixth grade students reported physical abuse. 50\% or more of children in Cambodia experienced physical abuse. About $50 \%$ of children in the Philippines experienced corporal punishment in schools. High and higher numbers are found all around the region, and qualitative reports support an assertion that violence against children is prevalent in ASEAN (Ratarsan, 2005; UNICEF, 2005; UN, 2006).

The most basic misconception held by persons who beat, batter, whip, spank, slap, hit, smack or otherwise assault children is that violence is somehow related to discipline. When adults, whether at home or school, violate laws and children's rights under the guise of civility and proper conduct, and when generations of people practice a system of authority dependent upon criminal or tortious behavior, children and adults alike become very confused and deluded. Only in a backwards, despotic world does immorality take on the impression of morality, and vice versa. Where and when abuse of children's rights is considered a lesser offense than government intervention to protect those rights, progress cannot occur. Overt, multifaceted public and private action, and support for changes of habit and culture which have for ages endangered the safety and wellbeing of children, are needed to stop the violence, but no change can happen without mothers and fathers simply protecting their children.

\subsection{Education}

In 2010, mean years of schooling among adults age 25 and older in ASEAN was 6.65 years. Adults age 25 and older in Cambodia, Indonesia, Laos, Myanmar, and Vietnam had less than six years of schooling on average (UNDP, 2010). While six out of ten ASEAN members are on track to meet MDG two on primary school enrolment (UNICEF, 2007), primary education alone will not lead to significant improvements in income and quality of life in a competitive AEC. Thailand, with its higher GDP per capita compared to other nations in the region, serves as a standard of comparison for the medium human development group - Thailand, Philippines, 
Indonesia, Vietnam, Cambodia, Laos - yet only $29 \%$ of females and $36 \%$ of males age 25 and older in Thailand have at least a secondary education (UNDP, 2013).

Education is related to, among other things, income, quality of life, economic competitiveness (WEF, 2013) and life expectancy (MNT, 2012). In a dynamic economy driven by science and technology, where math skills and computer literacy are essential, at least a secondary education is absolutely required to remain employed and productive. Ideally, everybody should earn a bachelor's degree, which should replace the high school diploma as the new bare-minimum. Without university degrees, workers cannot take advantage of ASEAN mutual recognition arrangements.

Agricultural yields and efficiency can be increased manifold through implementing scientific methods and incorporating technologies. Small businesses can benefit from theories of marketing, finance, logistics, managerial and organizational behavior. Sweatshop labour cannot exist in a society where individuals are educated about their rights and those of others. Opportunities for environmental degradation and exploitation of indigenous people are minimized through education. In sum, the devaluation of education is perhaps the single-most destructive social ideology the world has to offer today. Yet again, there are stubborn cultural values which factor into long-held beliefs that higher education is unnecessary. Archetypical changes are the most difficult variety to motivate.

\section{Discussion}

While the birth of a child is often anecdotally related to the happiest moments in a person's life, we find a breadth of evidence that as the child matures, individuals and societies exhibit less joy about the life. It is unarguably a parent's responsibility to feed, cloth, shelter, protect and begin to teach a child, but for a variety of reasons many parents are unable or unwilling to carry out their basic duties. Ideally, the State should step in and replace the parent in some way such that the child's development, health and wellbeing are not severely impeded. Such an ideal system breaks down, however, when the State does not have sufficient funds or political infrastructure to give benefits or place children in protective custody.

In the ASEAN group, average income lies below US $\$ 4,000$ per year (Note 8) and inflation outpaces wage rises (Australia DFAT, 2013). Education and good food are normal goods, so we can conclude that lack of education and food implies lack of economic means. Ideally, when a family is unable to provide necessity goods for a child, the government should supplement income or provide benefits. However, tax revenues in ASEAN fall far below OECD average levels, and individuals are unable to contribute further to tax bases, leaving seven of ten ASEAN governments without means to provide for and protect their people (OECD, 2013; World Bank, 2013).

The data and literature showed a trend across all themes: there simply is not enough money to fix the problems. Despite some variance between nations' domestic statutes, their apparent missions are generally in sync with prominent international values. The ASEAN Human Rights Declaration (2012) reaffirms commitments toward human rights. What is being said and written is sufficient, but disparity between stated commitments and actual results draws concern.

Annual Human Development Reports (UNDP, 2013) show correlations between income, institutional and social quality. In essence, micro-individual cases are representative of macro-collective conditions. People from poorer nations are more likely to experience extremely troublesome life phenomena such as human rights abuses. In turn, persons subjected to human rights abuses are more likely stuck in deep poverty (Amnesty International, 2013). Economic essentials like secondary education, student bussing, free school lunch, social housing, food stamps, and child protective services cannot be established and maintained without dramatic changes in public budgets.

Real, sustained, quantifiable improvements of living conditions and quality of life probably require both macroeconomic growth which supports per capita income growth, and more active local enforcement against human rights violators. Paradoxical conditions clearly exist whereby law enforcement cannot be funded without increased government revenue, which in turn cannot rise without the economic benefits of more civil societies. Lacking reform in tax collection, which is unlikely in the short and medium terms in the majority of the ASEAN group, public budgets will not likely support doubling or tripling of enforcement and corrections budgets, especially since prisons are already overcrowded in the region (Walmsley, 2011; ICPS, 2012). There are, fortunately, a couple "elephants in the room" that have not yet been seriously considered.

\subsection{Disruptive Policy Innovation for Social Change}

If police were to act in more ex officio capacity and undertake more proactive efforts on the issues of child sex tourism, it is likely that large seizures of cash and property could be witnessed, which could fund further efforts 
in the fight against children's rights abuses. Legalization of adult prostitution, such as in Singapore, could also help government officials regulate the age of sex workers while increasing tax bases and exponentially reducing money laundering. In the meantime, drinking establishments should be searched or raided for minors, and alcohol distribution outlets should be the subjects of investigations for furnishing to minors. Fines should be assessed for violations of laws, which would then increase police budgets. Furthermore, a comprehensive system of liquor, dancing, hotel, travel, tourism, and other entertainment licenses would increase public budgets, thereby giving governments more power to enforce laws.

The World Health Organization (WHO, 2009) considers opium and related drugs "essential medications". Few people are aware of licit opium cultivation worldwide, such as in Australia (TASDOJ, 2013), India (Bureau of Narcotics, 2013), Turkey (UNODC, n.d.), and Great Britain (Allen-Stevens, 2001). Considering that the problem of opium cultivation in the Golden Triangle region is persistent and supported by "local politicians and ex-state officials" (Kheunkaew and Khamthita, 2008), a licensing scheme could be developed to handle political concerns and improve tax revenues. Should opium crops be licensed and distributed through proper hospital channels, ex officio action against illicit producers in Thailand, Laos, and Myanmar would likely be easier to rationalize.

If public budgets can be increased significantly through some aggressive new policy, and/or by more active enforcement of older policies, then expenditures in education and social infrastructure may support broader improvements. Education and counseling services give people valuable skills and knowhow that can generate long-term returns, making individuals more self-sufficient, more productive, and more socially responsible. Children can be fed balanced meals at schools which have budgetary power to offer free or subsidized nutrition based upon reported family-reported income. Instead of turning a blind eye to vices of the region, authorities can look for opportunity in even the foulest segments of consumer markets. But only with a more mature, humble approach can one man's trash become another man's treasure.

\section{Conclusion}

None of the literature or legal documents reviewed suggested that child protection should not improve, nor that child protection today is at an entirely acceptable level. In fact, the near-unanimous opinion is that while most children today enjoy more rights than those in generations past, abuse is still at intolerable levels. Poverty and human rights abuse are clearly related, placing greater burden to protect upon governments whose people are impoverished, such as those in the Mekong subregion. Governments, unfortunately, cannot print their way out of economic turmoil, and lacking public revenues displace burdens of protection back onto private communities.

Potential revenues are available in the short and medium term through creative initiatives and much-needed political changes. AEC represents enormous opportunities for macroeconomic growth in the medium to long term, but there are no guarantees that such growth will occur or that its impacts will be widely spread. Alternative means of providing security and stability need to be explored and debated in the short term, perhaps offered to the public by way of democratic vote. By engaging in academic research and discussion of issues, with the aim of suppressing invalid arguments while supporting fact-based reasoning, real change can occur in ASEAN.

Still, increased government action is no panacea for human rights abuses. Governments are neither omnipotent nor infallible. Neither is more money the solution to a problem. Human rights abuses exist in every country, caused and perpetuated by a complex range of factors from inequity and mental illness to prejudice and passive aggression. While few people are directly involved in human rights abuses, it requires a great deal of ignorance and indirect support from bystanders who may consider altruism irrational. Police and courts need to react swiftly when violations occur, but proactive measures are probably the best route toward more civility, as told in the old idiom "An ounce of prevention is worth a pound of cure."

The most difficult part of any process of change will likely be gaining genuine support in communities. Modern political conditions in the ASEAN region are such that people may think and feel as though they love and support their governments or nations, but in practice they fail to uphold the fundamental principles upon which the states were formed. Human rights abuses not only violate sui generis statutes, but also trample Constitutional ideals. Unfortunately, courts are often ineffective and inefficient forums for handling cases involving Constitutional or human rights abuses, save the most appalling of incidents.

Human rights, whether for children or adults, emerge from the heart of communities based upon liberties which people agree are universally valid. Practice and protection of such rights must be a personal endeavor occurring in the home, at work, at school, and everywhere life takes place. Massive failures to protect children's rights as identified in this article are evidence that insufficient numbers of adults recognize and respect rights of children. 
Whether abuses are rationalized as "culture" or "tradition", continuance of such atrocities is not legally defensible, but where law itself is viewed with a suspicious eye and spoken of with a disdainful tone, little progress can be made.

In the process of drafting the Universal Declaration of Human Rights, the guideline for all modern human rights doctrine, Eleanor Roosevelt recognized the local origins of such rights. There is, perhaps, no more concise way to summarize this issue:

"Where, after all, do universal human rights begin? In small places, close to home...Unless these rights have meaning there, they have little meaning anywhere. Without concerted citizen action to uphold them close to home, we shall look in vain for progress in the larger world."

\section{References}

Allen-Stevens, T. (2001). First license is granted for British drug poppies. Farmers Weekly.

Amnesty International. (2013). Poverty and Human Rights. Retrieved April 5, 2014, from https://www.amnesty.org/en/poverty

Annan, K., \& Cardoso, F. (2013). Kofi Annan: Stor 'war on drugs'. CNN. Retrieved December 26, 2013, from http://edition.cnn.com/2013/11/05/opinion/annan-cordoso-humane-drug-policy/

Archard, D. (2010). Children's rights. Stanford Encyclopedia of Philosophy. Retrieved December 26, 2013, from http://plato.stanford.edu/entries/rights-children/\#ChiRigAduRig

ASEAN Framework Agreement on Mutual Recognition Arrangements. (1998).

ASEAN Human Rights Declaration. (2012).

Australia Government Department of Foreign Affairs and Trade. (2013). ASEAN 10. Retrieved April 5, 2014, from http://www.dfat.gov.au/geo/fs/asean.pdf

Bachhuber, E. (2003). Reluctant warriors? Monterey Institute of International Studies. Retrieved December 25, 2013, from http://sites.miis.edu/sand/files/2011/06/688-Child-Soldiers.pdf

Bergman, J. (2013). Can Burma avoid the curse of sex tourism? Time. Retrieved December 25, 2013, from http://world.time.com/2013/04/12/can-burma-avoid-the-curse-of-sex-tourism/

BJS. (2007). Drug use and crime. Retrieved December 26, 2013 from http://www.bjs.gov/content/dcf/duc.cfm

Bloom, I. (2009). Introduction to Confucian thought. Retrieved December 26, 2013, from $\mathrm{http} / / /$ afe.easia.columbia.edu/special/china_1000bce_confucius_intro.htm

Chatterjee, S. (2012). We needn't wait for conflicts to end for children to be removed from armed organizations. Retrieved December 25, 2013, from http://www.forbes.com/sites/realspin/2012/12/09/for-child-soldiers-every-day-is-a-living-nightmare/

Child Soldiers International. (2012). Louder than words. Retrieved December 25, 2013, from $\mathrm{http} / / /$ www.child-soldiers.org/global_report_reader.php?id=562

CIA. (2013). GDP per capita (PPP). Retrieved December 26, 2013, from https://www.cia.gov/library/publications/the-world-factbook/rankorder/2004rank.html

Cornell University. (2013). Jus Cogens. Retrieved December 26, 2013, from $\mathrm{http}: / / w w w . l a w . c o r n e l l . e d u / w e x / j u s \_c o g e n s$

Deng, F. (n. d.). Corrective justice in the Confucian legal tradition: a nonexistent concept. Peking University Law School. Retrieved December 26, 2013, from $\mathrm{http}: / /$ www.lawschool.cornell.edu/international/clarke_program/conferences/upload/dengfeng.pdf

DrugScope. (2013). How much crime is drug related? Retrieved December 26, 2013, from http://www.drugscope.org.uk/resources/faqs/faqpages/how-much-crime-is-drug-related

Economist. (2013). Thailand's drug wars: back on the offensive. Retrieved December 26, 2013, from http://www.economist.com/node/10566797

ECPAT. (2013). End child prostitution, child pornography \& trafficking of children for sexual purposes. Retrieved December 26, 2013, from http://www.ecpat.net/

FAO. (2012). FAO Statistical Yearbook: World Food and Agriculture. Retrieved December 25, 2013, from http://www.fao.org/docrep/015/i2490e/i2490e00.htm 
Fidler, D. (2013). International law. WHO. Retrieved December 26, 2013, from http://www.who.int/trade/distance_learning/gpgh/gpgh7/en/index3.html

Franklin and Eleanor Roosevelt Institute. (1998). Eleanor Roosevelt biography. UDHR. Retrieved December 27, 2013, from http://www.udhr.org/history/Biographies/bioer.htm

Gillespie, S., Haddad, L., \& Allen, L. (2001). Attacking the double burden of malnutrition in Asia and the Pacific. Asian Development Bank. Retrieved December 25, 2013, from http://www.ifpri.org/sites/default/files/pubs/pubs/books/double/double_ch02.pdf

Healey, J. (2011). Former Burmese child soldier to speak in Congress. Huffington Post. Retrieved December 25, 2013, from http://www.huffingtonpost.com/jack-healey/former-burmese-child-sold_b_915566.html

$\mathrm{Hu}, \mathrm{X} .$, \& Stowe, J. (2013). The effect of income on health choices: alcohol use. Southern Agricultural Economics Association Annual Meeting, Orlando, Florida, February 3-5, 2013. Retrieved December 26, 2013, from http://ageconsearch.umn.edu/bitstream/143060/2/Xiaowen $\% 20 H u-S A E A-I n c o m e \% 20$ and $\% 20$ Its\%20Effect $\% 20$ on\%20Health\%20Choice.pdf

IAS. (2011). Consumption levels by income earned. Retrieved December 26, 2013, from http:/www.ias.org.uk/Alcohol-knowledge-centre/Socioeconomic-groups/Factsheets/Consumption-levels-by -income-earned.aspx

ICPS. (2012). World prison $\quad$ brief: $\quad$ Asia. $\quad$ Retrieved from http://www.prisonstudies.org/info/worldbrief/?search=contasia\&x=Asia

ILO Convention (No. 138) concerning Minimum Age for Admission to Employment. (1973).

ILO Convention (No. 182) concerning the Prohibition and Immediate Action for the Elimination of the Worst Forms of Child Labour. (1999).

ILO. (2013). Marking progress against child labour. Retrieved December 26, 2013, from http://www.ilo.org/wcmsp5/groups/public/---ed_norm/---ipec/documents/publication/wcms_221513.pdf

India Central Bureau of Narcotics. (2013). Licit cultivation. Retrieved December 26, 2013, from http://cbn.nic.in/html/operationscbn.htm

International Centre for Science in Drug Policy. (2010). The Vienna Declaration. Retrieved December 26, 2013, from http://www.viennadeclaration.com/

INTERPOL. (2010). Legislation of INTERPOL member states on sexual offences against children. Retrieved December 25, 2013, from http://www.interpol.int

IOM. (2012). Child trafficking and labour trafficking cases rising. Retrieved December 26, 2013, from http://www.unric.org/en/human-trafficking/27458-child-trafficking-and-labour-trafficking-cases-rising-iom

Kaplan, E. (2005). Child soldiers around the world. Council on Foreign Relations. Retrieved December 25, 2013, from http://www.cfr.org/human-rights/child-soldiers-around-world/p9331

Kheunkaw, S., \& Khamthita, T. (2008). Golden Triangle opium production on the rise. Bangkok Post. Retrieved December 26, 2013, from http://euro-burma.eu/doc/November2008.pdf

Kulsudjarit, K. (2004). Drug problem in southeast and southwest Asia. Annals New York Academy of Sciences, 1025, 446-457. http://dx.doi.org/10.1196/annals.1316.055

LEAP. (2013). Law Enforcement against Prohibition. Retrieved December 26, 2013 from http://www.leap.cc/

Lederer, E. (2008). Conflicts using child soldiers declines. The Seattle Times. Retrieved December 25, 2013, from http://seattletimes.com/html/nationworld/2004428683_apunchildsoldiers.html

McDonald, H. (2013). 'It is time to end the war on drugs', says top UK police chief. The Guardian. Retrieved $\begin{array}{llll}\text { December } 26, \quad 2013, & \text { from }\end{array}$ http://www.theguardian.com/society/2013/sep/28/time-end-war-drugs-uk-police-chief

Mehta et al. (1998). Adolescents in Changing Times: Issues and Perspectives for Adolescent Reproductive Health in the ESCAP Region. UNESCAP. Retrieved from http://www.unescap.org/esid/psis/population/icpd/sec7.asp

MNT. (2012). Education lengthens life expectancy. Retrieved December 26, 2013, from http://www.medicalnewstoday.com/articles/248777.php

Obama, B. (2013). A $21^{\text {st }}$ Century Drug Policy. Office of National Drug Control Policy. Retrieved December 26, 
2013, from http://www.whitehouse.gov/sites/default/files/ondcp/policy-and-research/2013_strategy_ fact_sheet.pdf

OECD. (2013). Revenue statistics and policy challenges in Asia. Development Centre and Centre for Tax Policy and Administration. $\quad$ Retrieved April 5, 2014, from http://www.oecd.org/dev/asia-pacific/REVENUE\%20STATISTICS\%20Asia.pdf

Pengpid, S., \& Peltzer, K. (2013). Prevalence and psychosocial correlates of illicit drug use among school-going adolescents in Thailand. Journal of Social Science, 34(3), 269-275.

Petry, N. (2000). Effects of increasing income on polydrug use: A comparison of heroin, cocaine and alcohol abusers. Addiction, 95(5), 705-17. Retrieved December 26, 2013, from http://www.ncbi.nlm.nih.gov/pubmed/10885045

Potterton, L. (2009). Fighting malnutrition. IAEA Bulletin 50-2. Retrieved December 25, 2013, from http://www.unscn.org/layout/modules/resources/files/Fighting_Malnutrition.pdf

Punkrasin, C. (2008). Letter from the Permanent Mission of Thailand to the United Nations. Retrieved December 26, 2013, from http://www.un.org/ga/president/62/ThematicDebates/humantrafficking/thailand.pdf

Ratarsarn, Y. (2005). Recommendations from children on violence against children. UNICEF. Retrieved December 26, 2013, from http://www.unicef.org/eapro/Recommendations_Book.pdf

Rosales, A. (2011). US Ambassador's Statements on RP's Sex Tourism Have Basis - DFA. Philippines DEP'T OF FOREIGN AFFAIRS, Retrieved from http://www.cfo.gov.ph/index.php?option=com_content\&view=article\&id=1510:us-ambassadors-statementson-rps-sex-tourism-have-basis-dfa\&catid=109:overseas-filipino-new $\&$ Itemid= 840

Ruangkanchanasetr, S., Plitponkarnpim, A., Hetrakul, P., \& Kongsakon, R. (2005). Youth risk behavior survey: Bangkok, Thailand. Journal of Adolescent Health, 36(6), 227-235.

Rushing, R., \& Urbina, J. (2005). Fatal Attraction: A Qualitative Study of Western Clients of Sex Workers in Thailand, paper presented at Conference "Violence: A Game for Men?"

Save the Children. (2013). Food for thought report. Retrieved December 25, 2013, from http://www.savethechildren.org.uk/2013-05/food-thought-report

Shahabudin, S. (n. d.). Strategies of Civil Society to Address AIDS in Asia: Emphasis on the Sex Sector, U.N. Retrieved December 27, 2012, from http://www.un.org/womenwatch/daw/csw/hivaids/Shahabudin.html

Stout, D. (2013). Burma's opium production has hit record levels because farmers have no choice. Time. Retrieved December 26, 2013, from http://world.time.com/2013/12/19/burma-opium-production-hits-record-levels/

Tanielian, A. (2013). Illicit Supply and Demand: Child Sex Exploitation in ASEAN. National Taiwan University Law Review, 8(1), 97-140.

TASDOJ. (2013). Poppy production in Tasmania. Retrieved December 26, 2013, from http://www.justice.tas.gov.au/poppy/the_industry/poppy_production_in_tasmania

Tran, M. (2009). Burma rebels vow to stop using child soldiers. The Guardian. Retrieved December 25, 2013, from http://www.theguardian.com/world/2009/jul/07/burma-rebels-child-soldiers-vow

Tumlin, K. (2000). Trafficking in Children and Women: A Regional Overview, paper presented at Asian Regional High-level Meeting on Child Labour. http://www.ilo.org/public/english/region/asro/bangkok/child/trafficking/downloads/jakarta.pdf

UN Charter. (1945).

UN. (2006). Rights of the child. General Assembly report A/61/299. Retrieved December 26, 2013, from http://www.childrightscoalitionasia.org/wp-content/uploads/2011/04/SG_violencestudy_en-2.pdf

UN. (2011). Children and armed conflict. A/65/820-S/2011/250. Retrieved December 25, 2013, from http://unispal.un.org/UNISPAL.NSF/0/70BF34991DA5D6B08525788E004BA583

UN. (2013). The foundation of international human rights law. Retrieved December 26, 2013, from http://www.un.org/en/documents/udhr/hr_law.shtml

UNDP. (2010). HDI trends 1980-2010. Retrieved December 26, 2013, from hdr.undp.org/en/media/HDI-trends-1980-2010.xls 
UNDP. (2013). Human development report. Retrieved December 26, 2013, from http://hdr.undp.org/en/media/HDR_2013_EN_complete.pdf

UNESCAP. (2003). Adolescent substance use: risk and protection. Retrieved December 26, 2013, from http://addictionstudies.dec.uwi.edu/Documents/prevention/Adolescent_Risk_and_Protective_Factors.pdf

UNESCO. (2004). HIV/AIDS in the GMS. Retrieved December 25, 2013, from http://unesdoc.unesco.org/images/0013/001378/137891e.pdf

UNICEF. (2004). Despite progress, children's rights far from universal. Retrieved December 25, 2013, from http://www.unicef.org/media/media_24176.html

UNICEF. (2005). Regional assessment on violence against children in East Asia and the Pacific Region. Retrieved December 26, 2013, from http://www.unicef.org/eapro/activities_3675.html

UNICEF. (2006a). A quarter of the world's children seriously underweight. Retrieved December 25, 2013, from http://www.unicef.org/media/media_33724.html

UNICEF. (2006b). Progress for children. Retrieved December 25, 2013, from http://www.unicef.org/media/files/PFC_Nutrition.pdf

UNICEF. (2007). MDG2: achieve universal primary education. Retrieved December 26, 2013, from http://www.unicef.org/statistics/

UNICEF. (2012). Child maltreatment: prevalence, incidence and consequences in the East Asia and Pacific region. Retrieved December 26, 2013, from http://www.unicef.org/eapro/Child_Maltreatment.pdf

UNICEF. (2013). Child protection. Statistical indicators. Retrieved December 25, 2013, from http://www.unicef.org/protection/statistics.html

UNICEF. (n. d.). HIV/AIDS in the region: impacts \& risk factors. Retrieved December 25, 2013, from http://www.unicef.org/eapro-hivaids/general/situation_impacts.htm

UNODC. (2013a). World Drug Report. Retrieved December 26, 2013, from http://www.unodc.org/unodc/secured/wdr/wdr2013/World_Drug_Report_2013.pdf

UNODC. (2013b). Record-high methamphetamine seizures in Southeast Asia. Retrieved December 26, 2013, from https://www.unodc.org/southeastasiaandpacific/en/2013/11/regional-ats-launch/story.html

UNODC. (2013c). Golden Triangle opium production rises $22 \%$ in 2013, says UNODC. Retrieved December 26 , 2013, from https://www.unodc.org/southeastasiaandpacific/en/2013/12/opium-survey-report/story.html

UNODC. (n. d.). Turkey programme. Retrieved December 26, 2013, from http://www.unodc.org/pdf/turkey_programme.pdf

US Department of State. (2013). Trafficking in persons report. Retrieved December 26, 2013, from http://www.state.gov/j/tip/rls/tiprpt/2013/index.htm

Vienna Convention on the Law of Treaties. (1969).

Vienna Declaration. (2010).

VOA. (2009). Children's rights still violated 20 years after convention. Retrieved December 25, 2013, from $\mathrm{http}: / / \mathrm{www} . v 0 a n e w s . c o m / c o n t e n t / c h i l d r e n s-r i g h t s-c o n v e n t i o n-70613757 / 415780 . \mathrm{html}$

Walmsley, R. (2011). World prison population list (9th ed.). International Centre for Prison Studies. Retrieved from http://www.idcr.org.uk/wp-content/uploads/2010/09/WPPL-9-22.pdf.

WEF. (2013). The global competitiveness report. Retrieved December 26, 2013, from http://www.weforum.org/reports/global-competitiveness-report-2013-2014

WHO. (2009). Access to Controlled Medications Programme. Retrieved December 26, 2013, from http://www.who.int/medicines/areas/quality_safety/ACMP_BrNoteGenrl_EN_Feb09.pdf

WHO. (2011). Alcohol. Retrieved December 26, 2013, from http://www.who.int/mediacentre/factsheets/fs349/en/

WHO. (2013). Millennium Development Goals. Retrieved December 25, 2013, from http://www.who.int/mediacentre/factsheets/fs290/en/

World Bank. (2013). World Development Indicators. 


\section{Notes}

Note 1. Thailand Prostitution Prevention and Suppression Act (1996); Philippines Revised Penal Code, Article 202 (1930).

Note 2. United States v. Frank, 599 F.3d 1221 (11th Cir. 2010).

Note 3. Regina v. Klassen, 24292 BCSC 1762 (2008).

Note 4. Cambodia Labour Code, art. 177 (1997); Thailand Labour Protection Act, §44 (1998); Philippines Labour Code, art. 139 (1974).

Note 5. Indonesia Act Concerning Manpower, art. 68-70 (2003).

Note 6. Laos Labour Law, art. 41 (2006).

Note 7. Vietnam Labour Code, art. 164 (2012).

Note 8. 2013 GDP per capita US\$3,852.

\section{Copyrights}

Copyright for this article is retained by the author(s), with first publication rights granted to the journal.

This is an open-access article distributed under the terms and conditions of the Creative Commons Attribution license (http://creativecommons.org/licenses/by/3.0/). 